\title{
Pengaplikasian Program ZIN untuk Perencanaan Manajemen Sistem Jaringan Jalan di Kota Makassar
}

\author{
M. Isran Ramli ${ }^{1 *}$, S. A. Adisasmita ${ }^{1}$, Mubassirang Pasra ${ }^{1}$, Hajriyanti Yatmar ${ }^{1}$ \\ Departemen Teknik Sipil, Fakultas Teknik Universitas Hasanuddin ${ }^{1}$ \\ isranramli@unhas.ac.id*
}

\begin{abstract}
Abstrak
Permasalahan transportasi menjadi sangat penting seiring dengan pertumbuhan penduduk dan kegiatan ekonomi. Laju pertumbuhan penduduk yang didukung oleh laju kendaraan dengan fasilitas yang masih kurang memadai sangat membutuhkan perencanaan transportasi yang dapat menjadi solusi untuk melakukan mitigasi atau pencegahan terkait masalah transportasi yang dapat muncul. Makassar sebagai salah satu kota metropolitan dengan tingkat pertumbuhan kendaraan yang cukup tinggi yaitu 13-14 persen per tahun untuk sepeda motor dan 8-10 persen per tahun untuk kendaraan ringan/ mobil. Dalam hal pertumbuhan kendaraan yang terus meningkat setiap tahun, maka kondisi ini pada akhirnya diprediksi dapat mengakibatkan jaringan jalan yang ada menjadi kritis untuk dilalui oleh kendaraan karena tingkat pelayanan jalan tidak maksimal. Informasi terkait tingkat pelayanan jalan yang umumnya dihitung secara manual menggunakan Manual Kapasitas Jalan Indonesia 1997 dengan dukungan data hasil survey lalu lintas, survey kecepatan, survey kondisi geometrik jalan, dan survey lain yang mendukung informasi dalam penentuan indeks tingkat pelayanan jalan dapat dihitung dengan menggunakan aplikasi program yang lebih efektif dan efisien yaitu ZIN. Pengaplikasian program ZIN ini merupakan salah satu upaya dalam perencanaan manajemen sistem jaringan jalan yang lebih efektif dan efisien khususnya untuk jalan di Kota Makassar.
\end{abstract}

Kata Kunci: Perencanaan; Aplikasi ZIN; Jaringan; Jalan; Transportasi.

\begin{abstract}
Transportation problems have an important role due to population and economic growth. The population of that simultaneity with the vehicle growth factor without the inadequate facilities is one of the factors that contribute to the traffic problems. The mitigation is needed to prevent other transportation problems. Makassar is one of the Metropolitan City has a vehicle's growth factor 13-14 percent every year for motorcycle and $8-10$ percent for every year; due to this condition, the critical networks frequently saw in the road would be disrupted. The level of service (LOS) of road decreased. The information about the LOS basically formulated by the Indonesia Highway Capacity Manual (IHCM) as guidance needs basic survey data such as vehicle volume, speed gun test result, geometric condition, and others as supporting data. Basically, the manual calculation using ICHM can be formulated with effective and efficient using application ZIN. The application of ZIN as one of the planning management to find the more efficient for more road network, especially for Makassar.
\end{abstract}

Keywords: Planning; ZIN Aplication; Network; Road; Transportation.

\section{Pendahuluan}

Tingkat perjalananan masyarakat sangat didukung oleh ketersediaan ruang, fasilitas, sarana dan prasarana transportasi pada suatu wilayah. Permintaan akan tingkat perjalanan ini mengalami pertumbuhan dari tahun ke tahun seiring dengan bertambahnya penduduk. Pertumbuhan ini menuntut adanya perencanaan transportasi yang baik sehingga dapat melayani kebutuhan masyarakat akan transportasi. Pembangunan dan peningkatan kapasitas ruas jalan merupakan salah satu upaya yang dapat dilakukan oleh pemerintah dalam menyediakan fasilitas sarana dan prasarana infrastruktur jalan yang memadai bagi masyarakat (Sahrullah, 2017). Salah satu yang menjadi tolok ukur dalam upaya peningkatan sarana transportasi yang memadai sehingga tidak 
menimbulkan peluang hambatan dan antrian panjang yang sering terjadi pada suatu ruas atau simpang adalah tingkat pelayanan pada jalan (MI Ramli, 2020).

Ramli 2019 menyatakan bahwa tingkat pelayanan jalan merupakan suatu bentuk pengukuran layanan yang diberikan oleh suatu ruas atau simpang pada jalan yang memperlihatkan kondisi operasional lalu lintas yang penilaiannya dilakukan oleh para pengguna jalan yang dinyatakan dalam suatu satuan waktu, kecepatan, kebebasan bergerak, kenyamanan, hambatan lalu lintas, dan keselamatan. Penilaian kinerja suatu ruas jalan umumnya menggambarkan kondisi pelayanan lalu lintas secara operasional yang dinyatakan dalam ukuran yang terukur (Salle, 2019) seperti kecepatan rerata, tundaan, waktu tempuh, rasio kendaraan berhenti, dan peluang antrian.

Tingkat kepemilikan kendaraan yang terus meningkat setiap tahun merupakan masalah yang dapat menyebabkan arus lalu lintas menjadi tidak stabil, disamping itu tingkat ketertiban masyarakat dalam berkendara juga merupakan faktor penting (MI Ramli, dkk 2020) untuk menghindari konflik dan kemacetan lalu lintas. Hambatan samping atau pusat kegiatan yang ada seperti pertokoan, perkantoran, industri yang dapat mempengaruhi arus lalu lintas secara langsung juga menjadi salah satu peluang kemacetan arus lalu lintas pada suatu ruas jalan sehingga mempengaruhi tingkat pelayanan yang diberikan oleh jalan. Analisis tingkat pelayanan jalan ini memberikan informasi (Hasrul, 2019) yang dapat menjadi masukan untuk meninjau kondisi jalan serta upaya penanganan yang diperlukan untuk para pengguna jalan.

Pelayanan jalan memiliki peranan penting dalam manajemen transportasi khususnya di Kota Metropolitan seperti Makassar. Sebagai salah satu kota yang memiliki tingkat pertumbuhan kendaraan yang cukup tinggi yakni sekitar 13-14 persen per tahun untuk kendaraan roda dua, dan sekitar 8-10 persen per tahun untuk kendaraan roda empat (Ramli \& Hustim 2018) sementara pertumbuhan jalan hanya 0,001 persen per tahun. Kondisi ini dapat membuat seluruh jalan yang ada di Kota Makassar menjadi kritis sehingga membutuhkan data atau informasi (Syahlendra \& Ramli 2018) terkait tingkat pelayanan jalan untuk perencanaan penaggulangan masalah transportasi. Informasi terkait kondisi atau tingkat pelayanan jalan merupakan hal yang paling utama untuk diketahui sehingga membutuhkan perangkat lunak atau program yang dapat mempermudah dalam menentukan tingkat pelayanan jalan yang biasanya dihitung secara manual menggunakan menggunakan Manual Kapasitas Jalan Indonesia (MKJI, 1997) dengan dukungan data hasil survey lalu lintas, survey kecepatan, survey kondisi geometrik jalan, dan survey lain yang mendukung informasi dalam penentuan Indeks Tingkat Pelayanan (ITP) jalan.

Penentuan tingkat pelayanan jalan pada suatu jaringan jalan dapat dilakukan melalui suatu simulasi lalu lintas menggunakan program ZIN. Simulasi lalu lintas merupakan suatu model matematis transportasi menggunakan program (Irawan, 2018) untuk membantu dalam perencanaan sehingga dapat diketahui dampaknya dan dapat disusun upaya antisipasinya.

\section{Latar Belakang Teori}

Tingkat pelayanan jalan merupakan parameter yang sering digunakan untuk mengukur kinerja jaringan jalan yang ada. Indeks Tingkat Pelayanan (ITP) jalan menjadi alat ukur yang penting dalam memberikan penilaian terkait kondisi terkini dari pelayanan jalan. Dalam pengukurannya, tingkat pelayanan jalan menggunakan standar MKJI 1997.

Perhitungan terkait tingkat pelayanan jalan ini dimulai dari perhitungan terkait kapasitas suatu jalan yang dipengaruhi oleh beberapa faktor yaitu: 
a) Kondisi jalan: fasilitas yang disediakan, lebar jalan, lebar bahu jalan, kecepatan rencana, alineymen vertikal dan horizontal, dan lajur untuk "antrian" di samping.

b) Kondisi lalu lintas: komposisi dan jenis kendaraan, distribusi arah dan distribusi lajur.

c) Kondisi kontrol: kontrol dengan APILL (jumlah tahap, waktu siklus, waktu hijau, koordinasi), kontrol dengan prioritas (lalu lintas di jalan utama atau major street), dan kontrol dengan bundaran (layout dengan garis tengah bundar).

Faktor yang memengaruhi kapasitas jalan ini kemudian dihitung menggunakan rumus persamaan berikut.

$\mathrm{C}=\mathrm{C}_{\mathrm{O}} \times \mathrm{FC}_{\mathrm{w}} \times \mathrm{FC}_{\mathrm{sp}} \times \mathrm{FC}_{\mathrm{sf}} \times \mathrm{FC}_{\mathrm{cs}}$

Dimana:

$\mathrm{C}=$ kapasitas $(\mathrm{smp} / \mathrm{jam}), \mathrm{C}_{\mathrm{O}}=$ kapasitas dasar $(\mathrm{smp} / \mathrm{jam}), \mathrm{FC}_{\mathrm{w}}=$ faktor penyesuaian lebar jalan

$\mathrm{FC}_{\mathrm{sp}}=$ faktor penyesuaian arah lalu lintas, $\mathrm{FC}_{\mathrm{sf}}=$ faktor penyesuaian gesekan samping dan kereb

$\mathrm{FC}_{\mathrm{cs}}=$ faktor ukuran kota

Perhitungan kapasitas ini kemudian menjadi dasar untuk menghitung ITP yang dihitung dari rasio antara volume (V) kendaraan (survey langsung) dengan kapasitas.

$\mathrm{ITP}=\mathrm{V} / \mathrm{C}$

Dimana:

ITP = Indeks Tingkat Pelayanan, V = Volume kendaraan ( smp/jam), C = Kapasitas (smp/jam)

Rasio V/C ini kemudian dilakukan pengecekan dan diklasifikasikan sesuai dengan karakteristiknya sehingga terdefinisi tingkatannya. Berikut disajikan Tabel 1 terkait ITP untuk tiap-tiap kondisi lalu lintas.

Tabel 1. Kriteria tingkat pelayanan jalan

\begin{tabular}{|c|c|l|}
\hline $\begin{array}{c}\text { Tingkat } \\
\text { Pelayanan }\end{array}$ & Rasio V/C & \multicolumn{1}{|c|}{ Kriteria } \\
\hline A & $<0,60$ & $\begin{array}{l}\text { Arus bebas, volume rendah dan kecepatan tinggi, } \\
\text { pengemudi dapat memilih kecepatan yang dikehendaki }\end{array}$ \\
\hline $\mathrm{B}$ & $0,60 \mathrm{~V} / \mathrm{C}<0,70$ & $\begin{array}{l}\text { Arus stabil, kecepatan sedikit terbatas oleh lalu lintas, } \\
\text { pengemudi masih dapat bebas dalam memilih } \\
\text { kecepatannya. }\end{array}$ \\
\hline $\mathrm{C}$ & $0,70 \mathrm{~V} / \mathrm{C}<0,80$ & Arus stabil, kecepatan dapat dikontrol oleh lalu lintas \\
\hline $\mathrm{D}$ & $0,80 \mathrm{~V} / \mathrm{C}<0,90$ & $\begin{array}{l}\text { Arus mulai tidak stabil, kecepatan rendah dan berbeda- } \\
\text { beda, volume mendekati kapasitas }\end{array}$ \\
\hline $\mathrm{E}$ & $0,90 \mathrm{~V} / \mathrm{C}<1$ & $\begin{array}{l}\text { Arus tidak stabil, kecepatan rendah dan berbeda-beda, } \\
\text { volume mendekati kapasitas }\end{array}$ \\
\hline $\mathrm{F}$ & $>1$ & $\begin{array}{l}\text { Arus yang terhambat, kecepatan rendah, volume diatas } \\
\text { kapasitas, sering terjadi kemacetan pada waktu yang } \\
\text { cukup lama. }\end{array}$ \\
\hline
\end{tabular}




\section{Metode untuk Permasalahan Mitra}

Penentuan khususnya untuk tingkat pelayanan jalan selama ini dilakukan dengan manual menggunakan standar MKJI 1997 dengan menggunakan program Microsoft Excel. Perhitungan ini tidak memperlihatkan secara visual dengan pada kondisi ruas jalan atau jaringan jalan yang ditinjau. Tingkat pelayanan jalan berdasarkan standar hanya dapat menghitung hingga angka yang terbatas. Sehingga alternative solusi dalam skenario-skenario perencanaan solusi juga memungkinkan terjadinya bias. Hal lain yang menjadi penting adalah pada program Makrosimulasi ZIN ini juga dapat memberikan informasi tidak hanya berupa total volume kendaraan akan tetapi juga vector atau bangkitan dan tarikan berdasarkan arah pembebanan kendaraan pada jaringan jalan menggunakan fungsi hambatan sehingga dapat melakukan estimasi dan prediksi model yang sangat penting untuk perencanaan transportasi berupa pengembangan jaringan jalan yang ada.

Metode pemodelan dan simulasi adalah elemen penting dalam analisis perencanaan dan operasional transportasi. Simulasi lalu lintas ini sangat penting dalam perencanaan dan manajemen transportasi kota seperti perencanaan dalam lalu lintas ruas jalan, simpang, bundaran, underpass, dan lainnya. Simulasi menggunakan perangkat lunak ini memudahkan dan menghemat waktu dalam menentukan tingkat pelayanan jalan, skenario usulan untuk perencanaan jalan baru, serta evaluasi terhadap kondisi eksisting dari suatu tingkat pelayanan jalan melalui suatu bentuk visualisasi dari kondisi jaringan jalan berdasarkan zonasi yang menggunakan four step model dalam transportasi. Pembebanan kendaraan pada jaringan jalan yang mempengaruhi tingkat pelayanan jalan serta bantuan estimasi dari matrik asal tujuan dengan metode Furness dan fungsi delay menggunakan BPR 1964 merupakan salah satu fasilitas yang ada pada program ZIN ini sehingga memberikan banyak pertimbangan perhitungan tingkat pelayanan jalan tidak hanya secara matematis. Makrosimulasi ZIN juga merupakan suatu program yang sederhana sehingga tidak membutuhkan ruang atau kapasitas penggunaan ruang penyimpanan yang besar dalam penggunaannya. Menu yang ada pada program ini juga sederhana dan mudah dipahami serta peta jaringan jalan yang digunakan dapat menggunakan peta eksisting yang terupdate dari google maps, open stret maps, dan lainnya sehingga pada saat melakukan simulasi sesuai dengan peta jaringan jalan ada. Dari hasil sosialisasi ini, seluruh peserta diharapkan mampu untuk membangun jaringan transportasi jalan dan skenario serta meninjau tingkat pelayanan jalan yang sangat dibutuhkan untuk perencanaan dan manajemen transportasi. Hal lain yang juga penting yaitu peserta dapat memahami pendekatan alternatif dalam pemodelan makroskopik serta mendapatkan keterampilan dasar dalam pengelolaan software ini.

Kegiatan sosialisasi pengaplikasian program ZIN ini menjadi satu inovasi dalam hal pengembangan dan perencanaan transportasi khususnya Kota Makassar. Peserta yang mengikuti sosialisasi juga diharapkan dapat melakukan pemodelan dan simulasi terhadap potensial masalah transportasi yang ada khususunya tingkat pelayanan jalan yang ada pada suatu sistem jaringan jalan, scenario perencanaan untuk beebrapa jalan alternative dalam menghindari konflik atau peluang kemacetan serta dampak dari scenario yang diusulkan khususnya jaringan jalan yang ada di kota Makassar. Untuk itu partisipasi dari peserta/individu yang mengikuti sosialisasi ini diharapkan mampu memberikan masukan terkait permasalahan transportasi khususnya tingkat pelayanan jaringan jalan yang ada, alternatif dan perencanaan jaringan jalan, kendala, serta saran untuk pengembangan kegiatan. 
Berdasarkan uraian di atas, maka untuk sosialisasi model makrosimulasi program ZIN bertujuan untuk:

a. memberikan pengetahuan dan pembekalan bagi individu yang berminat mendalami pemodelan transportasi dan simulasi lalu lintas melalui praktek aplikasi software

b. mengetahui tahapan membangun jaringan model transportasi dan jalan raya serta skenario pembebanan jaringan jalan dan tingkat pelayanannya

c. memberikan keterampilan dasar dalam pengolahan software untuk pemodelan makroskopik yang meliputi, pengantar pemodelan transportasi dengan program ZIN, pengembangan model permintaan perjalanan 4 langkah, menyusun jaringan jalan dari data Google Earth dan Open Streeet Map, serta mengukur kinerja jaringan jalan dan mengetahui hasil keluaran dari skenario kondisi eksisting dan skenario alternative untuk perencanaan dan manajemen transportasi.

Pelaksanaan program sosialisasi ini juga mengharapkan peserta mampu menggunakan aplikasi berdasarkan studi kasus yang akan diberikan pada saat sosialisasi. Untuk tahap keberlanjutan dari kegiatan ini, komunikasi dengan laboratorium sistem transportasi dapat menjadi wadah untuk konsultasi dan pendalaman terkait pemodelan transportasi menggunakan Program ZIN ini dapat dilakukan.

\section{Hasil dan Diskusi}

Kegiatan sosialisasi pengaplikasian program ZIN ini telah terlaksanan di Departemen Teknik Sipil Unhas dengan registerasi peserta yang terbatas dan di utamakan untuk pihak-pihak yang terkait dan membutuhkan. Untuk itu sebelum kegiatan berlangsung, peserta telah registerasi secara online. Instruktur yang juga hadir adalah pihak pengembang dan penemu program ini untuk memberikan arahan dan bimbingan terkait penggunaan aplikasi ini bekerjasama dengan dosen ahli pada Laboratorium Sistem Tranportasi Departemen Teknik Sipil Unhas yang juga telah menggunakan dan mendapatkan lisensi dari program ZIN.

Dinas Perhubungan Kota Makassar sebagai mitra yang mendukung dan memfasilitasi kegiatan berupa data-data jaringan jalan kota, arah pengembangan jaringan jalan, dan data pendukung lainnya untuk menghasilkan model yang akurat sesuai dengan kondisi lapangan.

Bentuk permasalahan atau studi kasus yang ditangani adalah bagaimana melihat tingkat pelayanan jalan yang ada pada area Mall Panakukang Makassar. Pusat perbelanjaan ini merupakan salah satu kawasan yang padat akan kendaraan pada jam-jam sibuk sehingga kondisinya kemudian di simulasikan menggunakan Program ZIN. Data terkait simulasi diberikan kepada para peserta diberikan dengan node awal hingga akhir secara berurutan adalah sebagai berikut: J1. Boulevard - JalanAdhyaksa - J1.Pengayoman - J1.Bougenvile dengan nilai C = 3800 smp/jam, $F F=50 \mathrm{~km} / \mathrm{jam}$, data bangkitan tarikan (smp/jam) dalam tabel matriks berikut.

Tabel 2. Nilai bangkitan tarikan pada asal tujuan

\begin{tabular}{|c|c|c|c|}
\hline NO & 1 & 2 & 3 \\
\hline 1 & - & 4000 & 4500 \\
\hline 2 & 4500 & - & 3700 \\
\hline 3 & 4000 & 5000 & - \\
\hline
\end{tabular}


Pusat bangkitan tarikan berada di Hotel Swiss Bell In, Carefour Panakukang, dan daerah Pemukiman Jalan Adhyaksa. nilai Co $=4600$ dan $\mathrm{FF}=65 \mathrm{~km} / \mathrm{jam}$. Jaringan jalan kemudian di analisis dengan nilai validasi kendaraan lapangan diberikan pada Tabel 2. Nilai-nilai dati bangkitan dan tarikan pergerakan serta nilai validasi kendaraan lapangan, maka dibuatlah dalam simulasi aplikasi ZIN sehingga memungkinkan dapat dengan mudah secara visual terlihat level of service dari jaringan jalan yang telah dibuat. Informasi terkait jaringan jalan ini kemudian dapat menjadi dasar sebagai salah satu bentuk model makrosimulasi yang dapat memberikan informasi penting terkait perencanaan jalan yang akan dibangun atau terkait feasibility study.

Tabel 3. Validasi kendaraan lapangan

\begin{tabular}{|c|c|c|c|c|c|}
\hline NO & 1 & 2 & 3 & 4 & 5 \\
\hline 1 & - & 3851 & - & - & 3517 \\
\hline 2 & 3717 & - & 4217 & - & - \\
\hline 3 & - & 4171 & - & 3861 & \\
\hline 4 & - & - & 3171 & - & 5171 \\
\hline 5 & 3717 & - & - & 3717 & - \\
\hline
\end{tabular}

Dalam aplikasi ZIN terlihat dengan jelas skenario dari setiap tahapan pekerjaan yang dilakukan seperti menggambar node/ titik yang menghubungkan jaringan jalan yang terangkai kemudian dilakukan analisis salah satu bentuk alternative untuk mengurai potensi antrian panjang kendaraan. Berikut adalah salah satu visual dan input data awal yang dimasukkan dalam aplikasi ZIN.

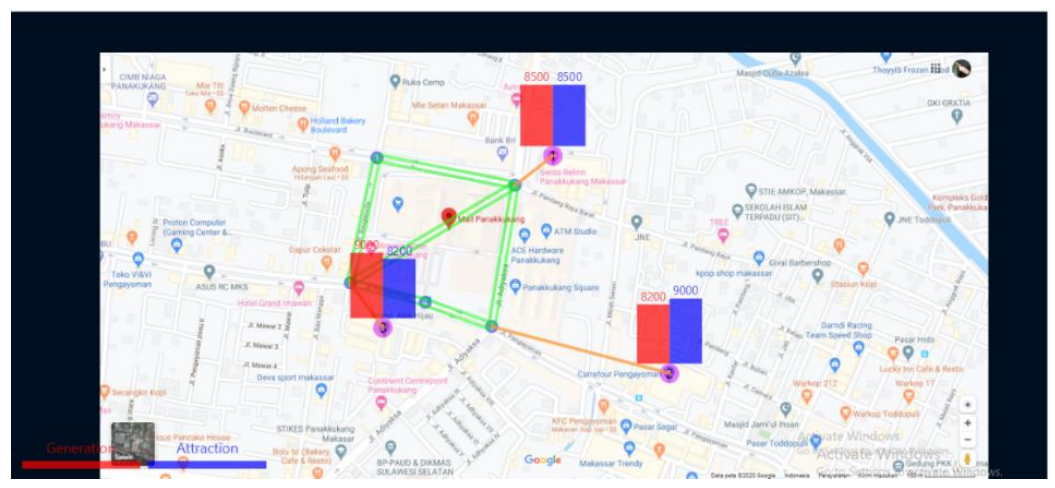

Gambar 1. Jaringan jalan dan nilai bangkitan tarikan

Aplikasi ZIN yang pada akhirnya akan memperlihatkan $L O S$ secara detail untuk wilayan yang telah digambarkan sehingga dapat memberikan visualisasi kondisi berdasarkan input yang diberikan. Berikut pada Gambar 2, terlihat dengan jelas jaringan jalan yang kemudian menjadi padat setelah dilakukan running terhadap parameter-parameter yang diberikan. 


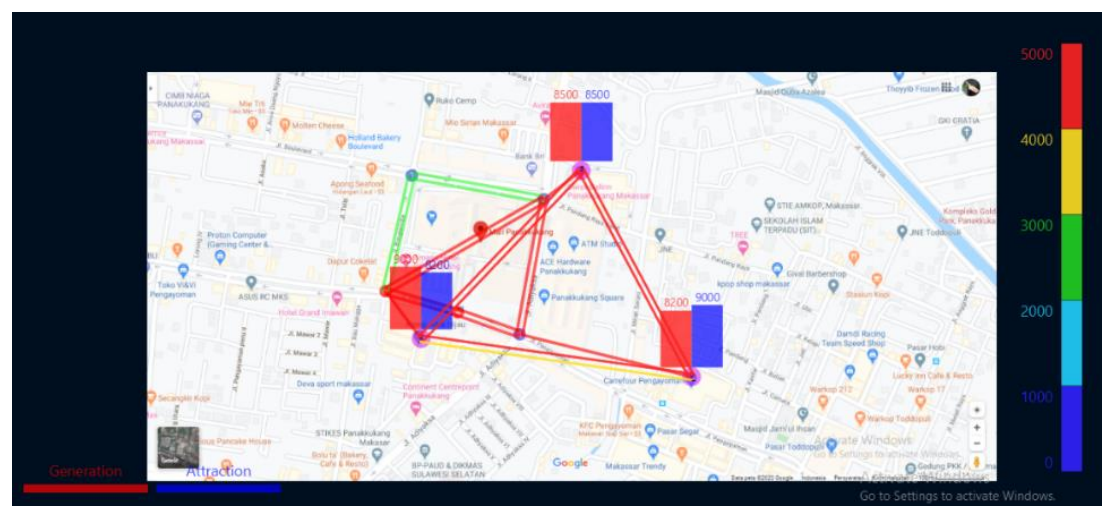

Gambar 2. Visualisasi pembebanan jaringan jalan

Aplikasi ZIN ini dengan jelas memperlihatkan jalur-jalur yang padat akan kendaraan sehingga antrian panjang yang dapat terjadi kemudian dapat diminimalkan. Hasil model simulasi makroskopik ini kemudian di validasi untuk meyakinkan bahwa model simulasi pada aplikasi ZIN dapat menjadi referensi untuk sumber informasi, maka digunakanlah analisa regresi. Berikut adalah hasil regresi yang disesuaikan dengan luaran dari program ZIN berupa data.

\section{Analisa Regresi R2}

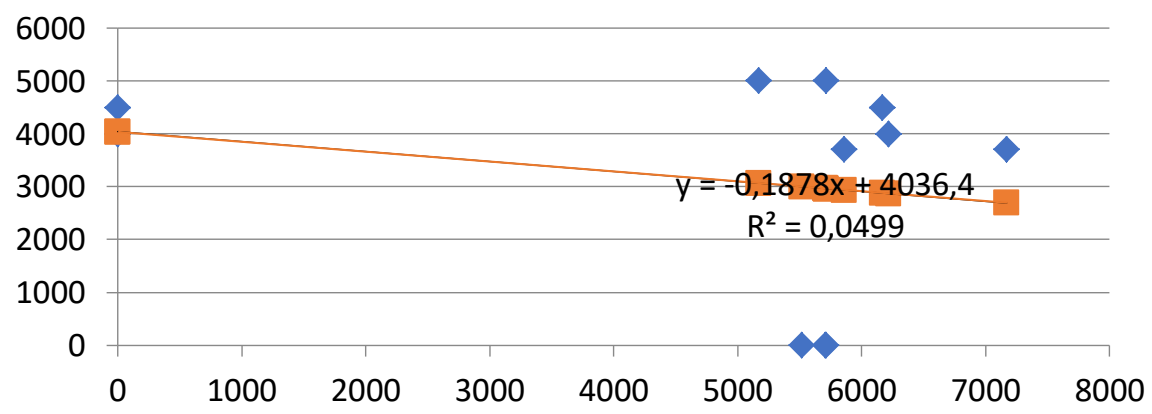

Gambar 3. Hasil validasi dengan R-Square

Hasil validasi ini juga merupakan output yang dari aplikasi ZIN yang memberikan nilai-nilai hasil running pada aplikasi kemudian dapat menjadi bahan informasi lebih lanjut untuk dapat disebar luaskan. Sehingga bentuk pelatihan ZIN pada akhirnya mampu memberikan kontribusi besar bagi para pemangku kepentingan terkait pengembangan jaringan jalan yang ada di Kota Makassar.

\section{Kesimpulan}

Pengaplikasian program ZIN dengan kolaborasi dengan para pemangku kepentingan yang dapat memberikan manfaat dalam hal pengembangan, pengelola, dan pemeliharaan. Aplikasi ZIN ini telah memberikan manfaat pada perencanaan dan evaluasi terkait indeks tingkat pelayanan jalan dengan studi kasus yang real sehingga mudah terimplementasikan. Aplikasi ZIN pada sosialisasi ini telah tepat sasaran untuk mengukur indeks tingkat pelayanan jalan dan skenario pembebanan serta dampaknya pada jaringan jalan di Kota Makassar. Hasil dari kegiatan sosialisasi ini diharapkan dapat memberikan informasi terkini sebagai preferensi bagi pemangku kepentingan terkait. 


\section{Saran}

Peserta yang banyak dengan waktu yang terbatas akan membuat panitia sedikit mengalami kesulitan, namun dengan manajemen yang kuat dan pelaksanaan rutin untuk meng-upgrade menggunakan pengaplikasian ZIN diharapkan mampu memberikan kontribusi.

\section{Ucapan Terima Kasih}

Penulis mengucapkan terima kasih kepada Dekan Fakultas Teknik Universitas Hasanuddin untuk dukungan pelaksanaan kegiatan Program Kemitraan Masyarakat (PKM) Universitas Hasanuddin khususnya kami para penulis juga kepada Kepala Dinas Perhubungan Makassar yang telah memberikan support data serta personil untuk turut hadir. Kegiatan penelitian untuk pengabdian ini adalah di bawah skema pengabdian Fakultas Teknik Universitas Hasanuddin sehingga kami ucapkan banyak terimakasih atas dukungan pendanaan dalam kegiatan ini.

\section{Daftar Pustaka}

Sahrullah, MI Ramli, N Ali, R Rahim, (2017). A Travel Time Estimation Model of Private Cars in Urban Arterial Roads Based on Heterogeneous Traffic. International Journal of Civil Engineering and Technology (IAEME) Publication Vol. 8 Issue 7, Pg. 676-685

MI Ramli, H Yatmar, (2020). Delay distribution estimation at a signalized intersection. IOP Conference Series: Earth and Environmental Science Vol. 419 - Pg. 012090

Muhammad Isran Ramli, Hajriyanti Yatmar, Muralia Hustim, Elvita Bellani, (2019). Study on Speeding Behaviour of Driver's Motor Vehicles to Traffic Accident Risk in National Road in Makassar City. Journal of Indonesia Road Safety, Vol. 2, Issue 3 Pg. 159-170

F. Salle, S.H. Aly, M.I. Ramli, (2019). Performance analysis of signalized intersection Jl. Haji Bau-Jl. penghibur-Jl. Rajawalin Makassar. International Journal of Innovative Technology and Exploring Engineering, Vol 8, Issue 4 Pg. 9-12

MI Ramli, D Runtulalo, H Yatmar, A Mangessi, (2020). An Estimation of Origin-Destination Matrices for a Public Transport Network in Makassar using Macrosimulation Visum. IOP Conference Series: Materials Science and Engineering Vol. 875 - Pg. 012027

Muhammad Reza Hasrul, Mubassirang Pasra, Muhammad Isran Ramli, (2019). Analisis Pembebanan Lalu Lintas terhadap Pengembangan Jaringan Jalan di Kawasan Perkotaan Mamminasata Berbasis Program EMME. Simposium XX Forum Studi Transportasi antar Perguruan Tinggi-2017 Vol. 20.

Muhammad Isran Ramli, Muralia Hustim, (2018). Efektifitas Pengoperasian Konstruksi Jalan Underpass dalam Mengurangi Kemacetan Lalu Lintas di Simpang Bandara Makassar. Konferensi Regional Teknik Jalan ke-14 HPJI

Muhammad Isran Ramli, Zarah A Hanami, Sumarni Hamid Aly, Mubassirang Pasra, Hustim Muralia, (2018). The Relationship Analysis between Motorcycle Emission and Road Facilities under Heterogeneous Traffic Situation. IOP Conf. Series: Earth and Environmental Science Vol. 140 Issue 1, Pages 1-9.

Syahlendra Syahlendra, Muhammad Isran Ramli, (2018). Studi Pemilihan Moda Angkutan Umum Untuk Pengguna Angkutan Kota Di Kota Makassar Berdasarkan Perubahan Variabel Biaya Perjalanan. Prosiding Forum Studi Transportasi antar Perguruan Tinggi-FSTPT

Departemen Pekerjaan Umum, (1997). Manual Kapasitas Jalan Indonesia (MKJI), Direktorat Jenderal Bina Marga dan Departemen Pekerjaan Umum Jakarta. 
| TEPAT Jurnal Teknologi Terapan untuk Pengabdian Masyarakat | Volume 3, Nomor 2, Tahun 2020

Muhammad Zuhdi Irawan, (2018). Tutorial Program Simulasi ZIN. Civil and Environmental Engineering Gadjah Mada University. 